\title{
Priming the dairy cow for lactation: a review of dry cow feeding strategies
}

\author{
Nicolas C. FRIGGENS ${ }^{\mathrm{a} *}$, Jens Bech ANDERSEN ${ }^{\mathrm{a}}$, Torben LARSEN ${ }^{\mathrm{a}}$, \\ Ole AAES ${ }^{\mathrm{b}}$, Richard J. DEWHURST ${ }^{\mathrm{c}}$
}

\author{
a Department of Animal Health and Welfare, Danish Institute of Agricultural Sciences, \\ Research Centre Foulum, PO Box 50, 8830 Tjele, Denmark \\ b Dansk Kvæg, Dansk Landbrugsrådgivning, Landscentret, Udkærsvej 15, 8200 Århus N, Denmark \\ c Institute of Grassland and Environmental Research, Plas Gogerddan, Aberystwyth, \\ Ceredigion SY23 3EB, UK
}

(Received 5 January 2004; accepted 28 April 2004)

\begin{abstract}
This paper reviews important aspects of dry cow feeding with emphasis placed on the preparation of the cow for the subsequent lactation. A number of feeding strategies, which have been proposed in recent years, are examined, alongside considerations of the effects of dry period length, levels of body reserves at calving and parity. A number of studies have reported the effect of varying the length of the dry period (in the range 0 to 70 days) on subsequent production and health. An 8 week dry period seems optimal though this should be adjusted to allow for the body condition score of cows at drying off. Avoiding extremes of body condition score at calving is desirable, so condition should be monitored throughout the lactation cycle. Attempting to achieve large changes in body reserves in the dry period has been associated with increased problems postpartum. The feeding strategies that are reviewed are strategies to decrease body mobilisation, prime for body mobilisation, prime the rumen for increased intake, prime for milk protein production and prime for calcium mobilisation and absorption. These strategies are also evaluated relative to their biological basis and reported physiological effects. Feeding high starch feeds in the latter part of the dry period was found not to provide clear benefits in terms of decreasing early lactation body mobilisation or increasing early lactation intake. Strategies aimed at priming the cow for the increased mobilisation of body lipid and body calcium that occurs in early lactation appear more favourable both from the point of view of making biological sense and from the available results reviewed.
\end{abstract}

\section{dry period / feeding / body condition score / dairy cattle / health}

Résumé - Préparation des vaches laitières à la lactation : bilan des stratégies d'alimentation des vaches taries. Cet article passe en revue les aspects importants de l'alimentation des vaches taries en mettant l'accent sur la préparation de la vache à la lactation suivante. Plusieurs stratégies d'alimentation proposées au cours des dernières années sont examinées, dans le même temps que des considérations portant sur les effets de la durée de la période sèche, du niveau des réserves corporelles au vêlage et du rang de lactation. Un certain nombre d'études ont montré que le fait de

* Corresponding author: n.friggens@agrsci.dk 
faire varier la durée de la période sèche (dans une plage de 0 à 70 jours) avait un effet sur la production et la santé lors de la lactation suivante. Une période sèche de 8 semaines semble optimale, quoiqu'elle doive être ajustée en tenant compte de la note d'état corporel des vaches au moment du tarissement. Il est préférable d'éviter des notes extrêmes au vêlage ; l'état corporel devrait donc être surveillé tout au long du cycle de lactation. Les tentatives de vouloir effectuer de grandes modifications du niveau des réserves corporelles pendant la période sèche ont été associées à une augmentation des problèmes postpartum. Les stratégies d'alimentation exposées ici ont pour objectif de : diminuer les mobilisations corporelles, préparer à la mobilisation des constituants de l'organisme, préparer le rumen à l'augmentation de l'ingéré, préparer à la production de protéines du lait, et préparer à la mobilisation et à l'absorption du calcium. Ces stratégies sont aussi évaluées sur leurs bases biologiques et leurs effets physiologiques mentionnés. Il n'a pas été mis en évidence que le fait de nourrir les animaux en fin de période sèche avec des aliments à haute teneur en amidon apportait des avantages clairs en terme de diminution de la mobilisation des réserves corporelles ou de l'augmentation de l'ingestion en début de lactation. Les stratégies visant une préparation accrue de la vache à la mobilisation des réserves lipidiques et calciques intervenant en début de lactation apparaissent plus favorables, tant du point de vue du sens biologique que des résultats disponibles étudiés.

période sèche / alimentation / note d'état corporel / vaches laitières / santé

\section{INTRODUCTION}

The notion that good nutritional management in the dry period is a pre-requisite for a good start to the subsequent lactation has become generally accepted. This idea is not new, "steaming up" in the dry period has been advocated since the 1930's [13]. However, dry cow feeding has attracted considerable scientific attention in recent years. This work has formed the basis for the many different proposed feeding strategies that are described and evaluated in this review. Unfortunately, it is increasingly evident that these strategies frequently appear to be contradictory. Some summarising and interpretation is needed in order for anything useful to be drawn from such a body of work. We therefore provide an evaluation of the biological sense of the different strategies and the evidence for the effectiveness of these strategies. The term "biological sense", as used here, means being in accordance with the normal, natural, teleophoretic changes in the cow's physiology orchestrated by her transition from pregnancy to lactation [see 39]. Those seeking a more detailed treatment of the literature, often with particular emphases, are referred to the reviews of Drackley [29], Drackley et al. [30], Grummer [52], Rémond et al. [97], and Goff and Horst [47].

\section{THE RATIONALE FOR DRY COW FEEDING STRATEGIES}

The main emphasis of feeding in the dry period is to prepare the cow for her subsequent lactation. Although the cow is growing both a foetus and a mammary gland during the dry period her nutritional requirements are low relative to lactation and can easily be met by a moderately good ration [e.g. 90 , 113]. This applies to both primiparous and multiparous cows though since primiparous cows are still growing they have greater requirements than multiparous cows.

The periparturient period is the period in which the cow has the highest risk of becoming ill. Disease frequencies relative to days from calving calculated from data collected within the Danish health recording scheme (Landskontoret for Kvæg) are shown in Figure 1. Figure 1 also shows the rate of change in milk yield through the periparturient period and into lactation. Even when shown in such simple terms as this, it is clear that the physiological machinery of the cow is subjected to a tremendous acceleration in early lactation. The correspondence between this acceleration and the frequencies of disease occurrence is striking. It is also worth noting that this process starts before calving (Fig. 1). Rapid change in the 

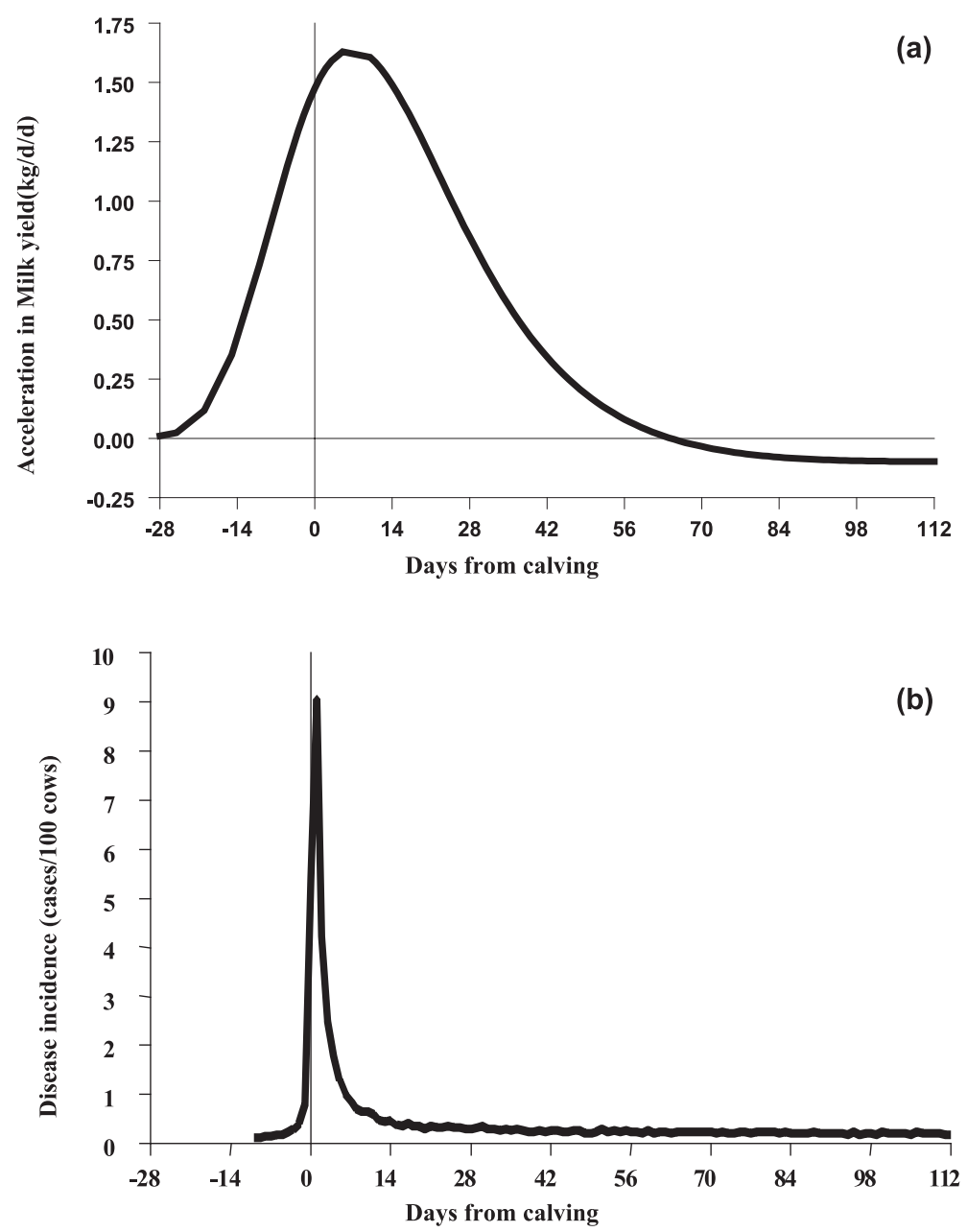

Figure 1. Acceleration in milk yield (a) and incidence of diseases (b) in early lactation. The disease data are for third parity cows ( $\mathrm{n}=58459$; Landskontoret for Kvæg).

rate of functioning causes stress in most systems, the cow is no exception. Consequently, any dry cow feeding strategy, which prepares the cow or primes the physiological system for this acceleration is likely to have beneficial effects. The feeding strategies, which have been proposed, are largely designed to prime the cows physiology. They can be categorised as strategies to:

- decrease body mobilisation,
- prime for body mobilisation,

- prime the rumen for increased intake,

- prime for milk protein production,

- prime for calcium mobilisation and absorption.

These strategies are discussed individually in Section 4. However, before discussing these priming strategies, there are some important and overriding considerations that 
first need to be taken account of when preparing the cow for her subsequent lactation, these are:

- dry period length,

- body reserves at calving,

- parity.

\section{GENERAL CONSIDERATIONS WHEN PREPARING THE COW FOR LACTATION}

\subsection{Dry period length}

Reports of the effects of dry period length on production in the following lactation can be found at least as far back as 1928 [102]. The vast majority of these studies have been based on observational data and come to the general conclusion that there is an optimal dry period length of 60 to 70 days, with shorter or longer dry periods resulting in lost production in the following lactation. However, because these studies use observational data there are serious flaws in most of this work. For instance, cows which are inherently low yielding tend to be dried off earlier, resulting in an unreliable correlation between dry period length and subsequent yield. These problems can be avoided by deliberately manipulating dry period length in a controlled experiment. The study of Sorensen and Enevoldsen [106] did just this.

Sorensen and Enevoldsen [106] found no evidence for a decrease in performance in the following lactation when dry period length was increased from 7 to 10 weeks. However, they did find that decreasing the length of the dry period from 7 to 4 weeks resulted in a significant decrease $(-2.8 \mathrm{~kg}$ fat corrected milk per $\mathrm{d}$ in the first $84 \mathrm{~d}$ ) in subsequent lactational performance. On the basis of this study, with herds yielding between 6000 and $9000 \mathrm{~kg}$ per lactation, it would appear that shortening the length of the dry period is not desirable. These findings have recently been confirmed in commercial herds with similar yields [31].
There is a good biological rationale for this effect of dry period length: once a cow has stopped milking, time is needed for mammary gland involution and subsequent regeneration [17].

However, there are well-documented cases of extremely successful commercial herds in which cows are not dried off at all before they calve [96]. The striking fact about these herds is that they are very high yielding. This suggests that it is more stressful to force very high yielding cows to dry off when they may still be giving $25 \mathrm{~kg}$ per $\mathrm{d}$ or more of milk than it is to continue milking them through until calving. It has also been argued that continuous milking should not be seen as an extreme shortening of the dry period, since there is no shutting down of milk production there is, in principle, no process of involution and, so, no need for subsequent regeneration. In contrast, attempts to reproduce the experience of the above, high yielding, commercial herds under research conditions have been less successful. Rémond and co-workers [98] tried to omit the dry period over three consecutive lactations beginning with the first lactation. Out of 27 cows that started the experiment, only 15 milked continuously from first through second lactation, and only 2 (out of 21 pregnant) also milked continuously from second through third lactation. In this study and in others [108] there was a negative effect of omitting the dry period on the subsequent lactation, which was in line with the findings of Sorensen and Enevoldsen [106]. All these experiments used cows of substantially lower yield than the commercial herds which have successfully omitted the dry period [97]. It is tempting to attribute the different outcomes to the yield difference although there may be other differences in, for instance, management, which are important. Further studies into the issue of dry period length are on-going with some preliminary reports of both negative effects [69] and no effect [95] of a shorter dry period which suggests that local conditions may be important. 
On balance, there is no reason to change the general recommendation of an 8 week dry period but this recommendation should be flexible to individual cows. Forcing cows to dry off from very high yields or forcing them to go on milking merely to achieve some preconceived dry period length is simply introducing unnecessary stress. Drying off cows with extreme yields has been associated with a substantially increased risk of mastitis [32].

\subsection{Body reserves at calving}

\subsubsection{Body fat}

A traditionally held view in practice is that overcondition at calving results in difficult calvings. There is evidence [76; A. Hameleers, unpublished data] to suggest that this is indeed so but only at extremely high levels of body condition i.e. condition scores greater than 4.5 (on a 5 point scale). As well as extreme maternal fatness, calf size is an important factor in calving difficulties. A recent British study (R.J. Dewhurst, unpublished data) showed increased calf weights $(46.8 \mathrm{~kg})$ for cows fed very high quality grass silage throughout the dry period as opposed to those that received a low digestibility silage throughout the dry period $(40.9 \mathrm{~kg})$. In the present context, the level of feeding likely to cause extreme fatness would also be likely to result in a bigger calf. Clearly, excessive overfeeding and excessive body fatness in dry cows must be avoided. However, with modern dairy cows fed to modern standards there is little evidence of such extreme fatness occurring.

Of far greater importance is the relationship between body fatness (condition) at calving and the subsequent rate of body mobilisation. As shown in Figure 2, high levels of body condition at calving usually lead to high rates of subsequent body mobilisation [2]. In turn, excessive rates of body mobilisation have repeatedly been linked to increased levels of health and reproduction problems. Butler and Smith [16] found that

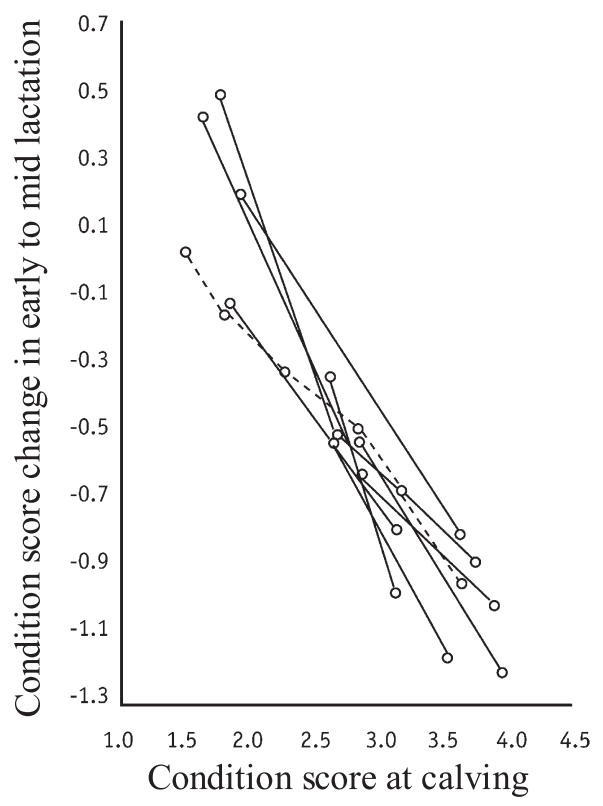

Figure 2. The relationship between body condition score at calving and condition score change in the first part of lactation. Reproduced from Broster and Broster [15] with permission.

days from calving to ovulation increased by 0.7 for each extra MJ energy being mobilised from body per day. Similarly, associations have been shown between body condition loss in early lactation and health problems $[45,100]$. Given the link between body fatness at calving and subsequent degree of mobilisation, it is clearly important to manage cows to calve at the optimum body fatness. There is general agreement $[14,42]$ that the optimum body condition at calving is around 3 (on a $1-5$ scale). This level of body reserves allows the cow a reasonable reserve to buffer any forthcoming dietary inadequacies without incurring excessive rates of postpartum mobilisation. However, as with optimal dry period lengths, individual variation between cows is to be expected in optimal condition score at calving. 
The notion that feeding in the dry period can be used to markedly change body condition is an erroneous one. In practice, there is a strong correlation between body condition at drying off and at calving, for the majority of cows the difference between drying off and calving condition is within \pm 0.5 units [77]. The length of the standard dry period (6-8 weeks) is such that achieving meaningful changes in body condition by feeding requires the use of extreme diets. In particular, attempting to drastically reduce the fatness of over-conditioned cows by severely restricting nutrient intake is a dangerous strategy. Such a strategy may ultimately impede mammary gland and ultimately foetal development, and will certainly cause excessive body mobilisation. Inclusion of barley straw in silage-based dry cow diets (at $40 \%$ of DM intake) led to the mobilisation of maternal body protein and reduced milk yields in the subsequent lactation [25, 83; R.J. Dewhurst, unpublished data]. Severe nutritional restriction should be avoided.

Management of feeding to achieve a desired level of body condition for calving should be considered well before the start of the dry period. In late lactation, cows have been shown to be resistant to dietary manipulation of their body reserves [62] therefore monitoring of body condition should be a process which occurs from the mid-lactation nadir onwards. This allows problems of overcondition to be avoided before they start. With regards to undercondition, that is, cows which are too thin, a useful strategy is to dry them off a week or two early [7]. This relieves these thin cows of the energy demands for milk and allows them more time to replenish reserves before the next lactation. In practice, the majority of cows will achieve their target calving condition score, without need for special nutritional intervention [36]. Cows that are already at their target calving condition score do not change condition score during the dry period under normal dry cow feeding conditions. Furthermore, cows that are thin at drying off have a tendency to gain condition whilst those that are very fat tend to lose condition during the dry period [7].

\subsubsection{Body protein}

Feeding dry cow diets with a very low crude protein content (less than $12 \%$ of dry matter) leads to mobilisation of maternal protein in support of the development of the conceptus [83] and at these levels, performance in the next lactation is impaired [18, 25]. As with most ruminant experiments, it is difficult to distinguish the effects of 'energy' and 'protein' but it is likely that some of the detrimental effects of feeding generally very poor rations to dry cows are due to a deficit of protein. At the other extreme, we have shown that dry cows will accrete additional nitrogen in their bodies, when fed high protein diets [83].

At least $25 \%$ of body $\mathrm{N}$ can be mobilised in support of lactation [12]. Diets that do not allow the cow to replenish depleted body protein reserves might conceivably also be a problem for dry cows. Our own studies (using the total $\mathrm{N}$ balance technique, R.J. Dewhurst, unpublished data) with cows of moderate yield potential showed substantial mobilisation of body $\mathrm{N}$ in early lactation. However, even in high forage systems, the cows were back in positive $\mathrm{N}$ balance by mid-lactation. Thus, body protein reserves are probably of little consequence to most cows once lactation is established. However, in this study, those cows which produced more milk mobilised more body protein so it could be envisaged that the incidence of problems with depleted body reserves may be growing as genetic potential for milk production advances.

Results such as these from total nitrogen balance studies, describe changes in the whole animal and may conceal important changes at the organ and tissue levels. Furthermore, relatively little is known concerning amino acid requirements. Recent work [6] has demonstrated a net mobilisation of methionine from peripheral tissues, suggesting that methionine is a limiting amino acid in typical (US) diets fed in the late dry 
period. At present, there is insufficient information at this level of detail to allow useful recommendations to be made about specific amino acids or for high protein feeding in the dry period. However, it is clear that dry cow rations should contain sufficient protein [e.g. 90] and low protein feeds should be avoided.

\subsection{Parity}

There is increasing evidence that the dry period between first and second lactation needs to be considered as a special case, particularly when primiparous cows have calved at a young age. High rearing costs and short life-spans in the milking herd have led to a reduction of age at first calving. Although there are now clear strategies for rapid rearing of primiparous cows, avoiding adverse effects on mammary development [104], these animals are still well below mature size in the first lactation. The continued requirements of these animals for growth will influence nutrient requirements during the dry period that follows their first lactation.

Berg and Ekern [9] conducted an experiment over the first 2 lactations of Norwegian Red cows. They studied 4 treatment groups, a $2 \times 2$ factorial arrangement of 'low' or 'high' levels of concentrates in the first and second lactations respectively. Despite giving the cows the opportunity to compensate by grazing them at pasture between lactations, there was a significant effect of underfeeding of primiparous cows carrying through into lower milk yields and milk protein concentrations in the second lactation.

Our own studies [26] have compared primiparous cows that calved for the first time at around 2-years with those that calved at around 3-years of age, or with older cows. Young primiparous cows that were underfed during the second gestation had reduced milk yields in the second lactation. Generous feeding of 2-year old primiparous cows in late lactation is a commonly advocated practice, with the objective of allowing these animals to grow. However, modern genotypes partition a large part of additional energy to milk production, even in late lactation [see also 62]. The dry period represents the only period when this can be avoided and animals complete their growth and replenish reserves. The experiment of Rémond et al. [98], discussed above showed that the omission of the dry period at the end of the first lactation had a substantial negative effect on subsequent yields of milk and milk solids, although milk fat and milk protein concentrations increased. As with the recommendations for achieving appropriate levels of body reserves at calving, success in avoiding problems with the first dry period depends on an early start to monitoring body condition and weight gain of primiparous cows accompanied by generous feeding when necessary.

\section{STRATEGIES TO PRIME THE DRY COW FOR LACTATION}

In this section the various strategies that have been proposed for improving lactational performance or reducing health problems in the subsequent lactation are discussed. In addition to the strategies discussed below, there are at least two other strategies which for lack of a sufficient literature base are not discussed. These are pre-milking of dry cows [see 54] and manipulating photoperiod [see 80].

\subsection{Strategies to decrease body mobilisation}

The basis for these strategies is the observation that cows usually start to mobilise body reserves towards the end of the dry period. There is a concomitant decline in intake through the dry period $[3,55,115]$. This dip in intake continues into the first week after calving [10, 49]. Such a dip in intake seems counter-intuitive when seen in relation to the increasing energy and nutrient requirements through the dry period and early lactation [8]. Consequently, it has been proposed that the energy content of dairy 
Table I. Summary of reported results concerning starch rich feeding in the dry period. Each different letter indicates a particular study ${ }^{\mathrm{a}}$, underlining indicates a strong effect.

\begin{tabular}{lccc}
\hline Effect & Yes & No & Unclear $^{\mathrm{b}}$ \\
\hline Increased energy intake in the dry period & abcdefg & & $\mathrm{h}$ \\
Increased milk yield and intake in lactation $^{c}$ & & $\underline{\text { ccdeff }}$ & agh \\
Increased insulin in lactation $^{\mathrm{c}}$ & $\mathrm{bf}$ & $\mathrm{a}$ & cdegh \\
Decreased blood NEFA in lactation $^{\mathrm{c}}$ & acf & de & bgh \\
Decreased liver fat in lactation $^{\mathrm{c}}$ & $\mathrm{e}$ & $\underline{\mathrm{bh}}$ & acdfg \\
\hline
\end{tabular}

a The studies, with the number of cows and days from calving at the start of the treatment given in parentheses, were: $\mathrm{a}=$ Kunz et al., 1995 (25, 70); $\mathrm{b}=$ Grum et al., 1996 (30, 60); c = Minor et al., 1998 (75, 19); $\mathrm{d}=$ Dann et al., $1999(65,28)$; e = Vandehaar et al., 1999 (80, 25); f = Holcomb et al., 2001 (41, 28); $\mathrm{g}=$ Rabelo et al., $2001(9,97) ; \mathrm{h}=$ Smith et al., $2003(74,21)$.

$\mathrm{b}$ Unclear or not reported.

c The lactation referred to is the first part of the subsequent lactation (see individual studies for the length of the recording period in lactation).

cow rations should be increased in the latter part of the dry period to counteract the dip in intake and thus decrease body mobilisation [53]. This is sometimes referred to as steaming-up and typically consists of increasing the non-fibrous carbohydrate content of the ration. As shown in Table I, there have been a number of studies that have investigated this dry cow feeding strategy [e.g. 22, 50, 57, 70, 81, 93, 115]. These studies all report a positive effect on dry period energy intakes of increasing the energy density of the ration (Tab. I).

One of the benefits proposed for high starch feeding in the dry period is that it may reduce body fat mobilisation by the following postulated mechanism. High levels of non-structural carbohydrate, in the ration are expected to result in an increased production of propionate by the rumen. High starch feeding reduces rumen $\mathrm{pH}$, inhibits fibre digesting microbes and hence fibre digestion and microbial protein synthesis in the rumen. This increased propionate is absorbed and metabolised by the liver to glucose which triggers an insulin response [61]. One of the targets of insulin is adipose tissue. The classic effect of insulin on fat metabolism is to inhibit the release of fatty acids from adipose tissue [19]. Thus it has been postulated that high energy feeding would act as a brake on body fat mobilisation [81]. Minor and co-workers found, on average, a significant decrease in the blood concentration of non-esterified fatty acids (NEFA) with high starch feeding over the period -19 to +60 days from calving. However, immediately after calving there was little difference between treatments in blood NEFA and no significant difference in energy balance at any time. A summary of the reported effects of high starch feeding on NEFA concentrations in blood and liver is shown in Table I. Some studies with high starch prepartum feeds have found lower levels of NEFA in blood after calving when compared to low starch controls [57, 70, 81]. Others have found no effect [22, 105 , 115]. The same appears to be true for liver fat content $[50,105,115]$. Through the periparturient period there are concerted changes in the endocrine control of the cows internal environment which include down regulation of sensitivity to insulin [see 61]. During this period, the classic effects of insulin are probably of much reduced importance. Furthermore, recent work at Foulum has shown that insulin infusion in lactating cows can depress the capacity of the liver to process fatty acids [4]. Thus high starch feeding in the dry period does not, in general, appear to be useful in the context of reducing body mobilisation immediately post-partum. 


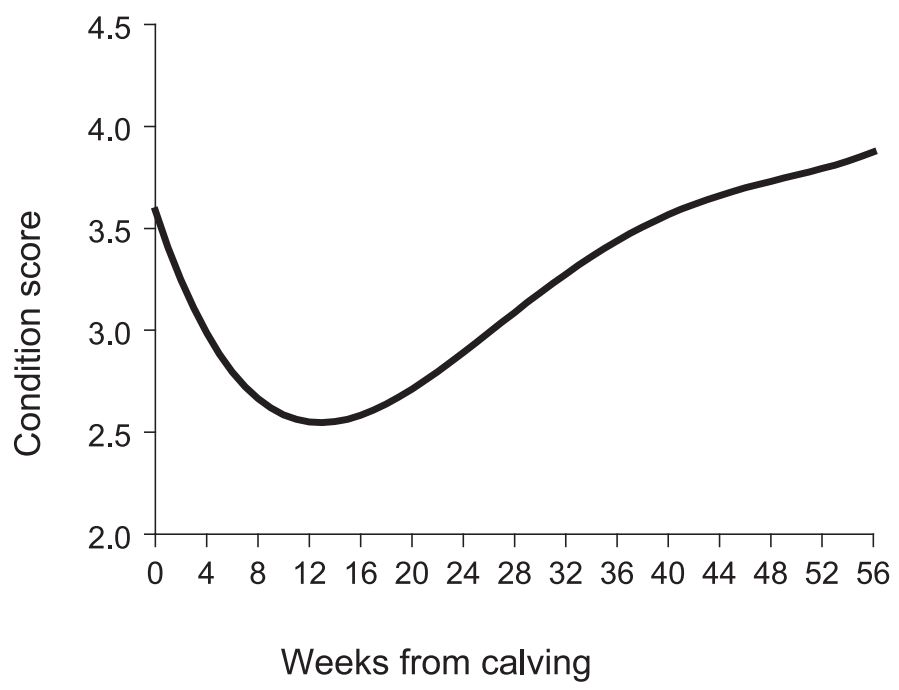

Figure 3. Changes in body fatness through the lactation cycle. Data of Nielsen et al. [86].

What is striking is that the majority of these experiments failed to find any effect of prepartum diet energy density on postpartum intake and milk production (Tab. I). Furthermore, in those experiments where the average level of dry period intake has been successfully increased, there is still a subsequent dip in intake in the days immediately prior to calving which is often more pronounced for the high energy fed cows such that at calving their intake is the same as that of lower energy fed controls [55, 57]. This strongly suggests that the dip in intake, and the concomitant body mobilisation, is not due to poor feeding management. Indeed, force-feeding cows (through a rumen fistula) to abolish the dip in intake during the dry period simply exacerbated the dip in intake after the force-feeding period was over [10].

There is good evidence to indicate that the peripartum dip in intake is a natural phenomenon common to the vast majority of mammals which results from the cow having a drive to mobilise her body reserves at this time [63]. The notion of a cow having a drive to mobilise at a particular time in her reproductive cycle is derived from considerations of genetic potential. It is well established that the milk production of a properly fed cow is a consequence of her genetic potential to produce milk, and that potential milk yield changes with time through lactation. There are also good evolutionary grounds [116] for assuming that cows have a potential or target level of body lipid which changes with time through lactation [37]. From these considerations, it is relatively easy to build up a picture of optimum levels of body lipid reserves changing throughout the reproductive cycle (see Fig. 3 and [39]). This picture is what is observed in the vast majority of mammals including dairy cows.

The practical consequence of this is that normal levels of body mobilisation in the periparturient period are perfectly natural and are no cause for concern [63]. Furthermore, because the cow has a high priority to mobilise in the peripartum period, increased ration energy density in the dry period will not eliminate this mobilisation [39]. Indeed, there is no decent evidence of 
any direct benefit of providing additional energy or protein over that supplied by an adequate dry cow ration [1].

In summary, the available evidence suggests that high starch feeding in the dry period does not, in general, appear to be useful in the context of reducing body mobilisation immediately post-partum, nor does it increase either intake or milk yield postpartum. Furthermore, there is increasing evidence that high starch feeding in the dry period is contrary to the normal, natural, changes in the cow's physiology and intake during the transition from pregnancy to lactation.

\subsection{Strategies to prime for body mobilisation}

Accepting that the cow will mobilise body reserves, and that the rate of body mobilisation will accelerate rapidly around calving, has resulted in a strategy based on physiological knowledge but taking a radically different approach to that described above. This is targeted at priming the cow to better deal with the increased concentrations of fatty acids in the blood postpartum by provoking an increase in circulating fatty acids in the late dry period.

In brief, relative to other species, the cow has a limited capacity to process fatty acids in the liver. When the uptake of fatty acids by the liver exceeds the livers' capacity to process them, these fatty acids are stored as fat in the liver. High levels of fat in the liver, called fatty liver syndrome, have been linked to impaired liver function and increased risk of ketosis [51]. However, it is likely that the capacity of the liver to process fatty acids is enhanced by exposure to increased concentrations of fatty acids in the blood. The reviews of Drackley [29, 30] elaborate this in greater detail and are recommended to those interested in this issue. Feeding a high fat ration in the dry period is a strategy to increase circulating levels of fatty acids thus attempting to pre-adapt the cows' liver to cope with increased fatty acids.
Grum and co-workers [50] fed a high fat $\operatorname{diet}(6.5 \%$ added liquid fat) from drying off until 7 days before expected calving. They also included a high starch and a control treatment. The high fat treatment significantly increased blood levels of NEFA during the dry period. Immediately after calving the lipid content of the livers of the high fat group was less than half that of the other two treatments (Fig. 4). It appears that elevated blood NEFA in the dry period primed the liver to cope with the increased mobilisation in early lactation. In terms of postpartum intake, milk production and body condition, there were no significant differences between the control and fat fed groups. On the basis of these results it is tempting to conclude that fat feeding in the dry period is a desirable strategy. However, including fat in the dry period diet also caused a significant decrease in dry period DM intake relative to the control, and a $10 \%$ lower energy intake. Although the elevated blood NEFA probably originated from the mobilisation of adipose tissue [50], it is not clear from this study what caused the elevated blood NEFA, the high fat content of the diet or the reduced energy intake. However, this group [28] carried out a follow up experiment to distinguish between these two possible effectors. Both reducing intake (to $80 \%$ of requirements) and including fat in the diet (under both ad libitum and restricted feeding) increased NEFA in the blood prepartum and resulted in lower liver lipid content postpartum. The effects of fat inclusion were smaller but additive to those of reduced intake. Recently, the results from additional studies support the finding that preventing excessive nutrient intake in the dry period has favourable effects on liver function and fat accumulation [21, 72].

The evidence that increased mobilisation of body lipid reserves primes the capacity of the liver to cope with circulating fatty acids must not be seen as an incitement to promote excessive mobilisation of body lipid. Fatty liver, ketosis and a multitude of other metabolic disorders in the post-partum cow are all predisposed by excessive 


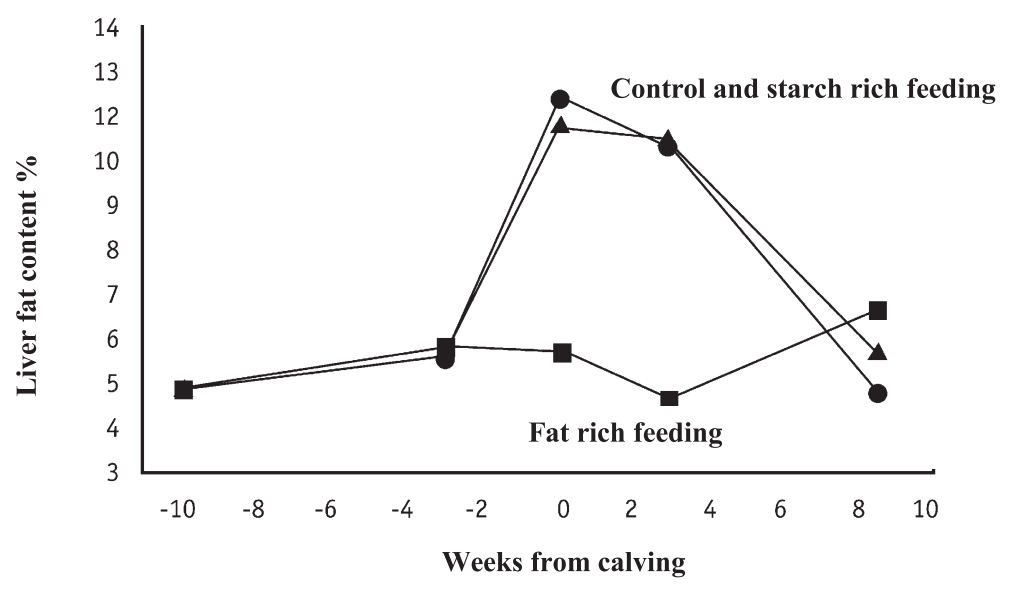

Figure 4. The effect of fat rich feeding in the dry period on liver fat content. Redrawn from Grum et al. [50] with permission.

mobilisation of body reserves [29, 45, 51, 67]. Reproductive performance is also impaired by excessive lipid mobilisation $[16,37]$. Excessive body lipid mobilisation after calving is, without doubt, to be avoided. What the evidence in this section suggests is that moderate mobilisation prior to calving is beneficial.

To summarise, a feeding strategy in the dry period which elevates fatty acid levels in the blood appears to have beneficial effects on the livers' capacity to process the increased amounts of fatty acid arising from body mobilisation in early lactation. This can be achieved in a number of ways. Restricting access to the energy rich component of the diet or feeding relatively high fibre i.e., low energy, rations will facilitate an early, and measured, start to mobilisation of the cow's own lipid reserves. Obviously, care must be taken to ensure that only a moderate increase in mobilisation occurs. Supplementation of the dry cow ration with fat will also increase circulating fatty acid levels. In contrast, supplementing basal dry cow rations with high starch feeds will, if anything, block this. Interestingly, the original proponent of "steaming up", who described the purpose of steaming up as "the idea is not to get cows fat but to get them as fit as fire", used palm kernel cake [13]. Palm kernel cake has a high content of fat and the majority of its carbohydrate is fibre rather than starch.

\subsection{Strategies to prime the rumen for increased intake}

It has been known for a number of years that the gastrointestinal system is capable of adapting to changes in the animal's age, physiological stage, feed level, feed composition, and partly to feeding management. In this section, we describe strategies in the dry period that have been postulated to increase the intake capacity of the rumen in the following lactation. The main focus of this section is on adaptations of the rumen epithelium, additionally rumen volume and adaptation of the microbial turnover are briefly discussed.

\subsubsection{Rumen epithelium}

Absorption of volatile fatty acids (VFA) takes place across the rumen epithelium. 
Feeding induced adaptations of rumen epithelium growth are largely due to propionate and butyrate in the rumen fluid [34, 35, $41,68,85,101]$. In the 1980's, German and Israeli scientists $[27,71,78]$ showed that a reduction takes place in the surface area of the rumen papillae due to reduced feed intake in the dry period, and that this reduction could partly be prevented by giving an energy-rich lactation feed throughout the dry period. This was proposed as a beneficial strategy because an increased area of rumen papillae results in an increased VFA absorption capacity through the rumen wall $[33,56,78]$, which in principle should result in a reduced risk of accumulating VFA in the rumen and thus reduce the risk of acidosis.

Based on the above, it has been postulated that the lower VFA absorption capacity in the rumen in early lactation was a contributory cause of a lower feed intake capacity in the periparturient period [89]. In order to improve the absorption capacity of VFA in the rumen in early lactation, a special dry cow feeding strategy called "acid load" was suggested in Denmark. "Acid load" was presented as $4 \mathrm{~kg}$ of rolled barley (or other feed rich in starch) at the morning feeding and $3.5-4.7 \mathrm{~kg}$ of silage DM at the afternoon feeding for the last 4 weeks of the dry period. Sehested et al. [103] found that cows subjected to "acid load" feeding had an increased in vitro capacity for the transport of butyrate over the rumen epithelium indicating that the "acid load" could result in an increased rumen capacity for VFA absorption. However, Andersen et al. [5] showed that the "acid load" clearly resulted in an increased production of propionate and butyrate in the rumen fluid but found no increase in the rumen papillae area or other signs of increased growth of the rumen epithelium at calving, and cows subjected to the "acid load" feeding had a quicker and larger drop in rumen $\mathrm{pH}$ after a feeding on days 8 and 28 postpartum. The conclusion is therefore that the "acid load" does not contribute significantly to a better rumen environment or an increased feed intake capacity in early lactation. These conclusions are moreover supported by recent results $[60,93]$.

\subsubsection{Microbial adaptation}

Adaptations of the microbial turnover in the rumen have also been widely discussed in the literature. It is a general assumption that the microorganisms in the rumen need up to several weeks to adapt to lactation feed at the start of a new lactation $[47,88]$, and these assumptions have primarily arisen from extreme feeding studies with steers. However, studies using sheep have shown that a gradual change in feeding from small to high amounts of concentrate does not affect the microbial flora significantly 1 and 7 days after a change in feeding [75]. In dairy cows, Friggens et al. [38] and Andersen et al. [3] have shown that large changes in the concentrate:roughage ratio, both in mid-lactation and at calving, resulted in a decrease in feed intake for only two days or no decrease at all. The quantitative importance of the adaptation of the microorganisms to a change in feeding in the periparturient period thus seems to be less important than previously believed, although conclusive evidence is lacking. However, it is not only the microorganisms of the rumen that have to adapt to changes in the periparturient period [61]. Sudden changes in feeding with significant changes in feed components (e.g. grass silage to corn silage) close to calving (especially in early lactation) should still be regarded as inappropriate for the digestion as well as for the metabolism of the cow.

\subsubsection{Rumen volume}

The possibility to adapt rumen volume to an increased intake capacity in the periparturient period has been discussed in the literature although only a few studies have dealt with this subject. Based on the results and discussions from Strudsholm et al. [107] and Dewhurst et al. [24], the conclusion seems to be that the possibility of adapting the rumen volume to an increased feed 


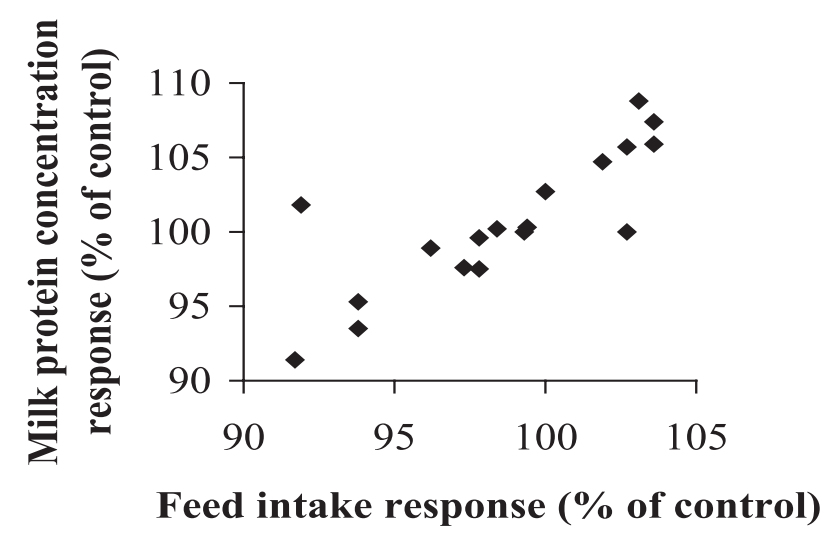

Figure 5. The effect of different levels of protein feeding in the dry period on subsequent milk protein content and feed intake. The results are shown as a response relative to control treatments. Based on treatment means taken from [20, 23, 40, 43, 44, 64-66, 74, 82, 87, 112].

intake is much more limited than previously believed. Indeed, physical regulation of feed intake in early lactation where rumen volume is a constituent factor is considered to be less important than previously believed [61].

In summary, feeding strategies in the dry period designed to prime the rumen for increased intake immediately after calving appear to offer, at best, rather modest benefits. Whilst it is generally agreed that it is beneficial to adapt dry cows to their lactation feed this process should be seen in the broader terms of reducing stress around calving and not just for any specific effects on stimulating postpartum intake.

\subsection{Strategies to prime for milk protein production}

Feeding supplemental protein during the dry period has been advocated as a means to increase milk protein production in the subsequent lactation. A number of potential mechanisms by which this may occur have been proposed. These include augmenting or sparing maternal protein reserves, improving rumen function, causing endocrine and metabolic changes. Some studies [82, 84, 109, 114] have demonstrated increased milk yields or milk protein $\%$ in response to the feeding of additional undegradable dietary protein during the dry period. Other studies have shown no effects [25; R.J. Dewhurst, unpublished data, 92, 115, 119] or a negative effect on milk production and milk protein \% [49]. When considered purely at the level of responses in milk yield it is difficult to make sense of the available literature. These apparently contradictory results strongly suggest that supplemental protein may have indirect as well as direct effects and that the relative size of these effects depends upon other factors (such as the basal diet, type and digestibility of forage/silage, etc.).

Whatever direct effects there may be, a likely indirect effect would be the effect of supplemental protein on intake. Indeed, there appears to be a relationship across experiments between the postpartum response in milk protein $\%$ and the postpartum response in intake (Fig. 5). It is well documented that supplemental protein improves the digestibility of poor forages, however, this does not adequately explain the fact that the effects of supplementing dry cow rations persist for up to 7 weeks into lactation [49]. It seems likely that this effect relates mainly to effects on body condition score at calving 
and, consequently, energy mobilisation in early lactation (Fig. 2). The improved digestibility of high protein dry cow rations may allow these cows to eat more and thus be in better condition at calving [e.g. 25]. All other things being equal, cows that are fatter at calving have lower intakes [15] and therefore correspondingly lower milk protein concentrations (Fig. 5).

Responses in intake do not account for all the variation in milk protein response (Fig. 5) suggesting that in some cases a direct response occurs. It may be that there is some carryover effect of feeding high protein dry cow rations on the efficiency of rumen microbial protein synthesis that contributes to absorbable amino acids and this effect may reflect on milk protein yield. It may also be that the size of body protein reserves has a direct effect on milk protein content, since a large proportion of the carbon skeletons in milk protein come from body reserves, rather than directly from the diet [118].

In summary, responses to protein supplementation in the dry period have been found to be rather variable. In the absence of definitive studies, feeding protein above requirements in the dry period is not recommended. Whilst there may be positive effects on milk protein, there is a potential for causing an increase in the number of overconditioned cows at calving and thus increased health and reproduction problems (see Sect. 3.2). There is also the danger of a negative effect on reproduction due to higher circulating urea levels [94].

\subsection{Strategies of adapting for mobilisation and calcium absorption}

Mineral nutrition, especially calcium, of the periparturient cow has been the subject of a considerable number of studies. Within the confines of the present review, this section can only provide a brief overview of this topic. A number of reviews focusing solely on minerals are available [e.g. 46, 59, 79, 111].
The turnover of minerals and trace elements is closely related to protein turnover. The need for minerals and trace elements depends on body size (maintenance) and production. For a cow in the dry and periparturient period, this means pregnancy and lactation. In the dry period, the development of the foetus, uterus, placenta, and amniotic fluid enters the last, accelerating, phase. Figure 6 shows the relationship between foetal growth and accumulation of selected minerals.

Generally, the mineral requirements of the cow are supplied by the natural mineral content of the feed, possibly supplemented with small amounts of inorganic minerals. Also in feeding, the general rule applies that the mineral content follows the protein content. When using extreme feed rations, such as very large proportions of straw (low protein content), mineral nutrition should be given special attention. The dry cow strategy of a reduced feed allocation thus results in a lower mineral supply from the feed.

Calcium plays an important part in the dry as well as the periparturient period which is partly due to the very considerable amount of calcium necessary for the initial milk production (colostrum contains approx. $2.3 \mathrm{~g}$ Ca per litre [58]). Colostrum production begins 1-2 days prepartum. This means a greater need for calcium - a drain from the cow's body to the milk in the udder - in this period. The initial milk production is normally reflected in the cow's pool of available calcium as the blood calcium drops in the periparturient period. These two conditions are shown in Figure 7. Furthermore, an acute calcium deficiency at calving will cause milk fever (parturient hypocalcaemia), a condition that has great consequences for the health of the cow and can be fatal [47, 91].

The pool of calcium available to the cow - and consequently the amount used for the milk production - is the sum of the absorption of calcium from the intestines and a certain mobilisation from the bone deposits. To prevent problems with the calcium supply 

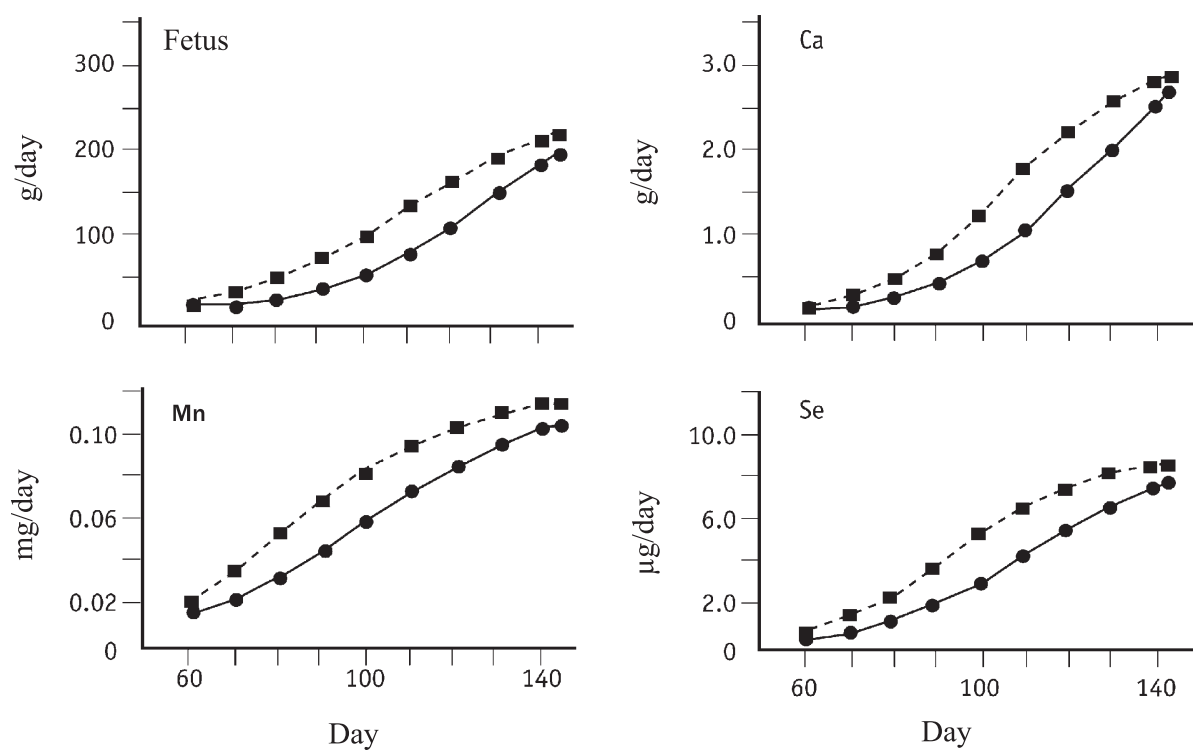

Figure 6. The relationship between mineral accumulation and growth in single (circles) or twin (squares) lamb foetuses (after Grace et al. [48]).

at the onset of lactation and considering the disease milk fever, two feeding strategies have been used in the dry period:

I. The "Anion-cation principle" is aimed at causing the systemic acidification of the organism via a changed balance between anions and cations in the feed and thus increase the resorption of calcium from the bones [11, 99].

II. The "Low calcium principle" (low calcium intake via the feed) is aimed at affecting the calcium absorption in the intestines and the mobilisation mechanism by under-supplying the organism for a period [73, 117].

The philosophy behind the "low calcium principle" is based on the fact that there is a homeostatic regulation of calcium absorption. When the feed is rich in calcium (compared to the physiological needs of the cow), only a small part of this calcium will be absorbed across the intestinal tissue. Conversely, when there is only a small amount of calcium in the feed, the cow will absorb a relatively larger amount of this calcium. The active agents in this regulation are the hormone PTH (parathyroid hormone), metabolites of vitamin D (particularly $\left.1.25(\mathrm{OH})_{2} \mathrm{D}_{3}\right)$, and calcium-binding proteins in the intestinal cells $(\mathrm{CaBP})$. When the calcium level in the bloodstream is low, PTH, $1.25(\mathrm{OH})_{2} \mathrm{D}_{3}$, and CaBP are produced in the organism, and together they promote the absorption of calcium from the intestines, mobilise calcium from the bones, and reduce the calcium loss via the urine, i.e. increase the calcium level in the body. Conversely, a "sufficient" calcium level will reduce the production of the regulating factors, so that the level of these declines, and consequently the calcium-mobilising mechanisms will be down regulated.

In practice, the "low calcium principle" prescribes low calcium intake in the dry period (as low as possible) and an escalation 1-2 days before calving. The low level in the dry period is supposed to ensure an increased production of PTH, $1.25(\mathrm{OH})_{2}$ 


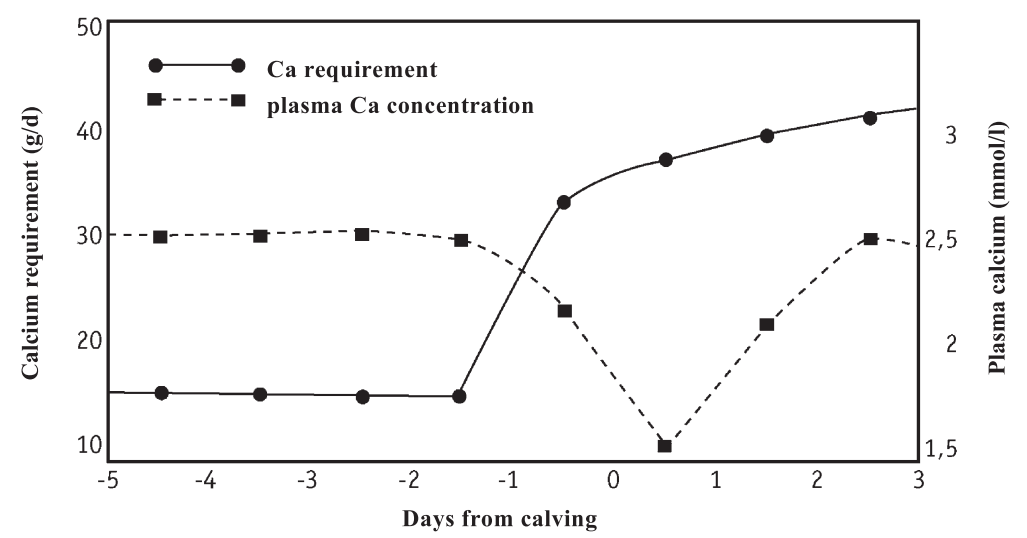

Figure 7. The cow's calcium requirements and plasma calcium concentration around calving (after Pickard [91]).

$\mathrm{D}_{3}$, and $\mathrm{CaBP}$, i.e. an increased "absorption potential", while the escalation in feed calcium immediately before calving is supposed to ensure the animal's increased need for calcium in this period (see Fig. 7), before the body's down-regulation of PTH, 1.25 $(\mathrm{OH})_{2} \mathrm{D}_{3}$, and CaBP sets in [91].

Danish norms recommend approx. $24 \mathrm{~g}$ of Ca per day in the beginning of the dry period (cow of $600 \mathrm{~kg}$ ) and an increase to approx. $33 \mathrm{~g}$ of Ca per day for the last 3 weeks. While the theoretical value of the "low calcium principle" is not in dispute, there is disagreement as to the practicability because, in practice, it is very difficult to limit the calcium intake to levels low enough to be considered physiologically active. Even a very controlled allocation of feeds (based on calcium content) - in an otherwise healthy and nutritious dry cow feed mixture - will often contain 40-50 g of calcium per day. Thus the question is whether there is any point in feeding "as low calcium as possible", or whether all calcium levels above a certain value "are equally good". There are keen advocates of both views, but true, unambiguous documentation does not seem to exist. Most studies indicate, however, that a low calcium allocation in the dry periodreduces the frequency of milk fever [59].
Realizing that it is difficult to practice the "low calcium principle", a Danish research group has introduced the idea of supplementing the feed with (chemical) calcium binders in the dry period. Preliminary results suggest this may be feasible, since the animals' blood calcium does not drop dramatically at calving [110].

To summarise, the onset of lactation is a very big challenge for the cow's calcium metabolism. The strategies currently advocated, however, are not to prepare the cow for the challenge by building up the storage of calcium via dry cow feeding but rather to prime the cow to be better able to regulate uptake and mobilisation of the calcium in the critical days around calving. Both strategies, the "anion-cation principle" and the "low calcium principle" demand a calculated and continuous effort in connection with the dry cow feeding. The use of lactation feeds in the late dry period without prior adjustment of their mineral contents is clearly not recommended.

\section{CONCLUSION}

An important aim of dry cow feeding strategies is to prepare the cow for the subsequent lactation. In addition to feeding 
strategies, consideration of the length of the dry period and the cows' body condition are important for problem-free milk production. Amongst the different feeding strategies currently proposed, the one that makes most biological sense and is increasingly producing favourable results in practice is the strategy to prime the cow for the increased body mobilisation that occurs in early lactation. This can be achieved by provoking a moderate energy deficit in the late dry period to facilitate an early, and measured, start to mobilisation of reserves. (This has also been achieved by feeding diets with an increased fat content.) Such a feeding strategy is in harmony with the cow's transition to an increased mobilisation of reserves at this stage of the lactation/reproductive cycle. In fact, attempts to counteract this effect and increase the supply of fermentable energy during this period have generally not benefited subsequent performance and have, in some cases, been shown to increase the incidence of metabolic disorders.

\section{REFERENCES}

[1] Aaes O., Andersen J.B., Ingvartsen K.L., Energiniveau og fodringsstrategi til køer goldperioden. 1. Virkning på mælkeproduktion, foderoptagelse, tilvækst og sundhed i tidlig laktation, in: Forskningsrapport fra Statens Husdyrbrugsfors $\emptyset$ g 22, Federiksberg Bogtrykkeri, Denmark, 1994, pp. 1-22.

[2] Agenäs S., Burstedt E., Holtenius K., Effects of feeding intensity during the dry period. 1. feed intake, body weight and milk production, J. Dairy Sci. 86 (2003) 870-882.

[3] Andersen J.B., Friggens N.C., Larsen T., Ingvartsen K.L., Effekten af energikoncentration i foderet og malkningsfrekvens hos malkekøer i tidlig laktation: Foderoptagelse, mælkeproduktion og mobilisering, Danmarks Jordbrugs Forskning, Forskningscenter Foulum, DJF rapport No. 22, 2001, 38 p.

[4] Andersen J.B., Mashed D.G., Larsen T., Nielsen M.O., Ingvartsen K.L., Effects of hyperinsulinaemia under euglycaemic condition on liver fat metabolism in dairy cows in early and mid-lactation, J. Vet. Med. A 49 (2002) 65-71.
[5] Andersen J.B., Sehested J., Ingvartsen K.L., Effect of dry cow feeding strategy on rumen $\mathrm{pH}$, concentration of VFA and rumen epithelium development, Acta Agr. Scand. A-An. 49 (1999) 149-155.

[6] Bach A., Huntington G.B., Stern M.D., Response of nitrogen metabolism in periparturient dairy cows to methionine supplementation, J. Anim. Sci. 78 (2000) 742-749.

[7] Bar D., Implementation of a body condition scoring program, Dansk Kvægfagdyrlægers Årsmøde, 25 Oktober 2001, 2001, pp. 4.14.6.

[8] Bell A.W., Regulation of organic nutrient metabolism during transition from late pregnancy to early lactation, J. Anim. Sci. 73 (1995) 2804-2819.

[9] Berg J., Ekern A., Long-term effects of concentrate level in dairy cows, Acta Agr. Scand. A-An. 43 (1993) 35-43.

[10] Bertics S.J., Grummer R.R., CadornigaValino C., Stoddard E.E., Effects of prepartum dry matter intake on liver triglyceride concentration and early lactation, J. Dairy Sci. 75 (1992) 1914-1922.

[11] Block E., Manipulating dietary anions and cations for prepartum dairy cows to reduce incidence of milk fever, J. Dairy Sci. 67 (1984) 2939-2948.

[12] Botts R.L., Hemken R.W., Bull L.S., Protein reserves in the lactating dairy cow, J. Dairy Sci. 62 (1979) 433-440.

[13] Boutflour R., The high yielding dairy cow, Crosby Lockwood \& Son Ltd., 1967, pp. 1160.

[14] Brand A., Noordhuizen J.P.T.M., Schukken Y.H., Herd health and production management in dairy practice, Wageningen Pers, 1996.

[15] Broster W.H., Broster V.J., Body score of dairy cows, J. Dairy Res. 65 (1998) 155-173.

[16] Butler W.R., Smith R.D., Interrelationships between energy balance and postpartum reproductive function in dairy cattle, J. Dairy Sci. 72 (1989) 767-783.

[17] Capuco A.V., Akers R.M., Mammary involution in dairy animals, J. Mammary Gland Biol. 4 (1999) 137-144.

[18] Chew B.P., Murdock R.R., Riley R.E., Hillers J.K., Influence of prepartum dietary crude protein on growth hormone, insulin, reproduction and lactation, J. Dairy Sci. 67 (1984) 270-275.

[19] Chilliard Y., Ferlay A., Faulconnier Y., Bonnet M., Rouel J., Bocquier F., Adipose tissue metabolism and its role in adaptations to undernutrition in ruminants, Proc. Nutr. Soc. 59 (2000) 127-134. 
[20] Cowan R.T., Reid G.W., Greenhalgh J.F.D., Tait C.A.G., Effects of feeding level in late pregnancy and dietary protein concentration during early lactation on food intake, milk yield, liveweight change and nitrogen balance of cows, J. Dairy Res. 48 (1981) 201212.

[21] Dann H.M., Litherland N.B., Underwood J.P., Bionaz M., Drackley J.K., Prepartum nutrient intake has minimal effects on postpartum dry matter intake, serum nonesterified fatty acids, liver lipid and glycogen contents, and milk yield, J. Dairy Sci. 86 (Suppl. 1) (2003) 106.

[22] Dann H.M., Varga G.A., Putnam D.E., Improving energy supply to late gestation and early postpartum dairy cows, J. Dairy Sci. 82 (1999) 1765-1778.

[23] Davenport D.G., Rakes A.H., Effects of prepartum feeding level and body condition on the postpartum performance of dairy cows, $\mathrm{J}$. Dairy Sci. 52 (1969) 1037-1043.

[24] Dewhurst R.J., Aston K., Fisher W.J., Evans R.T., Dhanoa M.S., McAllan A.B., Comparison of energy and protein sources offered at low levels in grass-silage-based diets for dairy cows, Anim. Sci. 68 (1999) 789-799.

[25] Dewhurst R.J., Moorby J.M., Dhanoa M.S., Evans R.T., Fisher W.J., Effects of altering energy and protein supply to dairy cows during the dry period. 1 . Intake, body condition, and milk production, J. Dairy Sci. 83 (2000) 1782-1794.

[26] Dewhurst R.J., Moorby J.M., Dhanoa M.S., Fisher W.J., Effects of level of concentrate feeding during the second gestation of Holstein-Friesian dairy cows. 1. Feed intake and milk production, J. Dairy Sci. 85 (2002) 169177.

[27] Dirksen G., Liebich H.G., Brosi G., Hagemeister H., Mayer E., Resorption von Kurzkettigen Fettsäuren aus dem Pansen des Rindes in Abhängigkeit von der Schleimhautstruktur: II. Funktionelle Befunde, Proc. XIII World Buiatrics Congress, Durban, 1984, pp. 629-633.

[28] Douglas G.N., Drackley J.K., Overton T.R., Bateman H.G., Lipid metabolism and production by Holstein cows fed control or high fat diets at restricted or ad libitum, J. Dairy Sci. 81 (Suppl. 1) (1998) 295.

[29] Drackley J.K., Biology of dairy cows during the transition period: the final frontier? $\mathrm{J}$. Dairy Sci. 82 (1999) 2259-2273.

[30] Drackley J.K., Overton T.R., Douglas G.N., Adaptations of glucose and long-chain fatty acid metabolism in liver of dairy cows during the periparturient period, J. Dairy Sci. 84 (Suppl. E) (2001) E100-E112.
[31] Enevoldsen C., Sammenhænge mellem goldperiode og sundhed samt produktion efter kælvning med udgangspunkt i danske og israelske data, Danske Kvægfagdyrlægers Årsmøde 2000, Hotel Munkebjerg, Vejle, 2000, pp. 1-29.

[32] Enevoldsen C., Sørensen J.T., Effects of dry period length on clinical mastitis and other major clinical health disorders, J. Dairy Sci. 75 (1992) 1007-1014.

[33] Fell B.F., Weekes T.E.C., Food intake as a mediator of adaptation in the ruminal epithelium, in: McDonald I.W., Warner A.C.I. (Eds.), Digestion and metabolism in the ruminant, The University of New England Publishing Unit, 1975, pp. 101-118.

[34] Flatt W.P., Warner R.G., Loosli J.K., Influence of purified materials on the development of the ruminant stomach, J. Dairy Sci. 41 (1958) 1593-1600.

[35] Flatt W.P., Warner R.G., Loosli J.K., Evaluation of several techniques used in the study of developing rumen function, Cornell University, Memoir 361, 1959, pp. 3-31.

[36] Friggens N.C., Huldets betydning for produktion og reproduction, Boologisk Selskabs Seminar, Sept. 16-17, 1999, pp. 55-62.

[37] Friggens N.C., Body lipid reserves and the reproductive cycle: towards a better understanding, Livest. Prod. Sci. 83 (2003) 209226.

[38] Friggens N.C., Emmans G.C., Kyriazakis I., Oldham J.D., Lewis M., Feed intake relative to stage of lactation for dairy cows consuming total mixed diets with a high or low ration of concentrate to forage, J. Dairy Sci. 81 (1998) 2228-2239.

[39] Friggens N.C., Ingvartsen K.L., Emmans G.C., Prediction of body lipid change in pregnancy and lactation, J. Dairy Sci. 87 (2004) 988-1000.

[40] Fronk T.J., Shultz L.H., Hardie A.R., Effect of dry period overconditioning on subsequent metabolic disorders and performance of dairy cows, J. Dairy Sci. 63 (1980) 10801090.

[41] Gàlfi P., Neogrady S., Sakata T., Effects of volatile fatty acids on the epithelial cell proliferation of the digestive tract and its hormonal mediation, in: Tsuda T., Sasaki Y., Kawashima R. (Eds.), Physiological aspects of digestion and metabolism in ruminants, Proc. Seventh Int. Symp. on Ruminant Physiology, 1991, pp. 49-59.

[42] Garnsworthy P.C., The effect of energy reserves at calving on performance of dairy cows, in: Garnsworthy P.C. (Ed.), Nutrition and lactation in the dairy cow, Butterworths, 1988 , pp. $157-170$. 
[43] Garnsworthy P.C., Huggett C.D., The influence of the fat concentration of the diet on the response by dairy cows to body condition at calving, Anim. Prod. 54 (1992) 7-13.

[44] Garnsworthy P.C., Jones G.P., The influence of body condition at calving and dietary protein supply on voluntary food intake and performance, Anim. Prod. 44 (1987) 347-353.

[45] Gearhart M.A., Curtis C.R., Erb H.N., Smith R.D., Sniffen C.J., Chase L.E., Cooper M.D., Relationship of changes in condition score to cow health in Holsteins, J. Dairy Sci. 73 (1990) 3132-3140.

[46] Goff J.P., Treatment of calcium, phosphorus, and magnesium balance disorders, Vet. Clin. N. Am.-Food A. Practice 15 (1999) 619-631.

[47] Goff J.P., Horst R.L., Physiological changes at parturition and their relationship to metabolic disorders, J. Dairy Sci. 80 (1997) 12601268.

[48] Grace N.D., Watkinson J.H., Martinson P., Accumulation of minerals by the foetus(es) and conceptus of single- and twin-bearing ewes, New Zeal. J. Agr. Res. 29 (1996) 207222.

[49] Greenfield R.B., Cecava M.J., Johnson T.R., Donkin S.S., Impact of dietary protein amount and rumen undegradability on intake, peripartum liver triglyceride, plasma metabolites, and milk production in transition dairy cattle, J. Dairy Sci. 83 (2000) 703-710.

[50] Grum D.E., Drackley J.K., Younker R.S., LaCount D.W., Veenhuizen J.J., Nutrition during the dry period and hepatic lipid metabolism of periparturient dairy cows, J. Dairy Sci. 79 (1996) 1850-1864.

[51] Grummer R.R., Etiology of lipid-related metabolic disorders in periparturient dairy cows, J. Dairy Sci. 76 (1993) 3882-3896.

[52] Grummer R.R., Impact of changes in organic nutrient metabolism on feeding the transition dairy cow, J. Anim. Sci. 73 (1995) 28202833.

[53] Grummer R.R., Transition cow energy, protein nutrition examined, Feedstuffs 14th Sept. 1998, pp. 11-23.

[54] Grummer R.R., Bertics S.J., Hackbart R.A., Effects of prepartum milking on dry matter intake, liver triglyceride, and plasma constituents, J. Dairy Sci. 83 (2000) 60-61.

[55] Grummer R.R., Hoffman P.C., Luck M.L., Bertics S.J., Effect of prepartum and postpartum dietary energy on growth and lactation of primiparous cows, J. Dairy Sci. 78 (1995) 172-180.

[56] Hinders R.G., Owen F.G., Relation of ruminal parakeratosis development to volatile fatty acid absorption, J. Dairy Sci. 48 (1965) 1069-1073.
[57] Holcomb C.S., Van Horn H.H., Head H.H., Hall M.B., Wilcox C.J., Effects of prepartum dry matter intake and forage percentage on postpartum performance of lactating dairy cows, J. Dairy Sci. 84 (2001) 2051-2058.

[58] Horst R.L., Goff J.P., Reinhardt T.A., Buxton D.R., Strategies for preventing milk fever in dairy cattle, J. Dairy Sci. 80 (1997) 12691280.

[59] Houe H., Østergaard S., Thilsing-Hansen T., Jørgensen R.J., Larsen T., Sørensen J.T., Agger J.F., Blom J.Y., Milk fever and subclinical hypocalcaemia - an evaluation of parameters on incidence risk, diagnosis, risk factors and biological effects as input for a decision support system for disease control, Acta Vet. Scand. 42 (2001) 1-29.

[60] Ingvartsen K.L., Aaes O., Andersen J.B., Effects of pattern of concentrate allocation in the dry period and early lactation on feed intake and lactational performance in dairy cows, Livest. Prod. Sci. 71 (2001) 207-221.

[61] Ingvartsen K.L., Andersen J.B., Integration of metabolism and intake regulation: a review focusing on periparturient animals, $\mathrm{J}$. Dairy Sci. 83 (2000) 1573-1597.

[62] Ingvartsen K.L., Danfær A., Andersen P.H., Foldager J., Prepartum feeding of dairy cattle: a review of the effect on periparturient metabolism, feed intake, production and health, Stocarstvo 50 (1996) 401-409.

[63] Ingvartsen K.L., Friggens N.C., Faverdin P., Food intake regulation in late pregnancy and early lactation, in: Oldham J.D., Simm G., Groen A.F., Nielsen B.L., Pryce J.E., Lawrence T.L.J. (Eds.), Metabolic stress in dairy cows, BSAS Occasional Publication 24, Edinburgh, Scotland, 1999, pp. 37-54.

[64] Jaquette R.D., Rakes A.H., Croom W.J., Effect of body condition and protein on milk fat depression in early lactation in dairy cows, J. Dairy Sci. 71 (1988) 2123-2134.

[65] Jones G.P., Garnsworthy P.C., The effects of body condition at calving and dietary protein content on dry-matter intake and performance in lactating cows given diets of low energy content, Anim. Prod. 47 (1988) 321-333.

[66] Jones G.P., Garnsworthy P.C., The effects of dietary energy content on the response of dairy cows to body condition at calving, Anim. Prod. 49 (1989) 183-191.

[67] Jorritsma R., Jorritsma H., Schukken Y.H., Wentink G.H., Relationships between fatty liver and fertility and some periparturient diseases in commercial Dutch dairy herds, Theriogenology 54 (2000) 1065-1074.

[68] Kauffold P., Voigt J., Herrendörfer G., Untersuchungen über den Einfluss von Ernährungsfaktoren aud die Pansenschleimhaut, Arch. Tierernährung 27 (1977) 201-211. 
[69] Kjeldsen A.M., Goldperioder under fire-fem uger giver store tab i ydelse. MåndesMagasinet Kvæg 10, 2003 Oct. 14, København, Denmark, Dansk Landbrugs Medier, 2003, pp. 8-9.

[70] Kunz P.L., Blum J.W., Hart I.C., Bickell H., Landis J., Effects of different energy intakes before and after calving on food intake, performance and blood hormones and metabolites in dairy cows, Anim. Prod. 40 (1985) 219-232.

[71] Liebich H.G., Mayer E., Arbitman R., Von Dirksen G., Strukturelle Veränderungen der Pansenschleimhaut hochproduzierender Milchkühe von Beginn der Trockenperiode bis acht Wochen Post Partum, Proc. 12th World Buiatrics Congress, Amsterdam, 1982, pp. 404 410.

[72] Litherland N.B., Dann H.M., Hansen A.S., Drackley J.K., Prepartum nutrient intake alters metabolism by liver slices from peripartal dairy cows, J. Dairy Sci. 86 (Suppl. 1) (2003) 105.

[73] Littledike E.T., Goff J.P., Interactions of calcium, phosphorus, magnesium and vitamin D that influence their status in domestic meat animals, J. Dairy Sci. 65 (1987) 1727-1743.

[74] Lodge G.A., Fisher L.J., Lessard J.R., Influence of prepartum feed intake on performance of cows fed ad libitum during lactation, J. Dairy Sci. 58 (1975) 696-702.

[75] Mackie R.I., Gilchrist F.C., Changes in lactate-producing and lactate utilizing bacteria in regulation to $\mathrm{pH}$ in the rumen of sheep during stepwise adaptation to a high-concentrate diet, Appl. Environ. Microb. 38 (1979) 422430.

[76] Maree C., The influence of high level feeding on the duration of parturition and the incidence of dystocia in dairy cows, J. S. Afr. Vet. Assoc. 57 (1986) 151-153.

[77] Markusfeld O.N., Implementation of BCS in integrated herd health and production management, Boologisk Selskabs Seminar, April 17-18 1997, pp. II.4.1.-II.4.10.

[78] Mayer E., Liebich H.G., Arbitman R., Hagemeister H., Dirksen G., Nutritionally induced changes in the rumenal papillae and in their capacity to absorb short chain fatty acids in high producing dairy cows, XIV World Congress on Diseases of Cattle, Dublin, 2, 1986, pp. 806-817.

[79] McNeil D.M., Roche J.R., McLachlan B.P., Stockdale C.R., Nutritional strategies for the prevention of hypocalcaemia at calving for dairy cows in pasture-based systems, Aust. J. Agr. Res. 53 (2002) 755-770.

[80] Miller A.R.E., Erdman R.A., Douglass L.W., Dahl G.E., Effects of photoperiodic manipulation during the dry period of dairy cows, J. Dairy Sci. 83 (2000) 962-967.
[81] Minor D.J., Trower S.L., Strang B.D., Shaver R.D., Grummer R.R., Effects of nonfiber carbohydrate and niacin on periparturient metabolic status and lactation of dairy cows, J. Dairy Sci. 81 (1998) 189-200.

[82] Moorby J.M., Dewhurst R.J., Marsden S., Effect of increasing digestible undegradable protein supply to dairy cows in late gestation on the yield and composition of milk during the subsequent lactation, Anim. Sci. 63 (1996) 201-213.

[83] Moorby J.M., Dewhurst R.J., Tweed J.K.S., Dhanoa M.S., Beck N.F.G., Effects of altering the energy and protein supply to dairy cows during the dry period. 2. Metabolic and hormonal responses, J. Dairy Sci. 83 (2000) 1795-1805.

[84] Murphy J.J., Effect of dry period protein feeding on post/partum milk production and composition, Livest. Prod. Sci. 57 (1999) 169-179.

[85] Neogrady S., Gàlfi P., Kutas F., Effects of butyrate and insulin and their interaction on the DNA synthesis of rumen epithelial cells in culture, Experientia 45 (1989) 94-96.

[86] Nielsen H.M., Friggens N.C., Løvendahl P.L., Jensen J., Ingvartsen K.L., The influence of breed, parity and stage of lactation on lactational performance and the relationship between body fatness and live weight, Livest. Prod. Sci. 79 (2003) 119-133.

[87] Nocek J.E., Steele R.L., Braund D.G., Prepartum grain feeding and subsequent lactation forage program effects on performance of dairy cows in early lactation, J. Dairy Sci. 69 (1986) 734-744.

[88] Noeck J.E., Bovine acidosis: Implications on laminitis, J. Dairy Sci. 80 (1997) 1005-1028.

[89] Nørgaard P., Saliva secretion and acid-base status of ruminants. A review, Acta Agr. Scand. A-An. Suppl. 89 (1993) 93-100.

[90] NRC, Nutrient requirements of dairy cattle, National Academy Press, 2001, pp. 1-363.

[91] Pickard D.W., Calcium requirements in relation to milk fever. Recent Developments in Ruminant Nutrition, Eds. Haresign and Cole, Butterworths, 1981, pp. 248-257.

[92] Putnam D. E., Varga G. A., Dann H. M., Metabolic and production responses to dietary protein and exogenous somatotropin in late gestation dairy cows, J. Dairy Sci. 82 (1999) 982-995.

[93] Rabelo E., Bertics S.J., Mackovic J., Grummer R.R., Strategies for increasing energy density of dry cow diets, J. Dairy Sci. 84 (2001) 2240-2249.

[94] Rajala-Schultz P.J., Savillw W.J.A., Frazer G.S., Wittum T.E., Association between milk urea nitrogen and fertility in Ohio dairy cows, J. Dairy Sci. 84 (2000) 482-489. 
[95] Rastani R., Grummer R., Shorter dry periods look good, Hoard's Dairyman, Sept. 25, 2003, p. 599.

[96] Rémond B., Bonnefoy J.C., Performance of a herd of Holstein cows managed without the dry period, Ann. Zootech. 46 (1997) 3-12.

[97] Rémond B., Kérouanton J., Brocard V., Effets de la réduction de la durée de la période sèche ou de son omission sur les performances des vaches laitières, INRA Prod. Anim. 10 (1997) 301-315.

[98] Rémond B., Rouel J., Pinson N., Jabet S., An attempt to omit the dry period over three consecutive lactations in dairy cows, Ann. Zootech. 46 (1997) 399-408.

[99] Roche J.R., Dalley D., Moate P., Grainger C., Rath M., O'Mara F., A low dietary cationanion difference precalving and calcium supplementation postcalving increase plasma calcium but not milk production in a pasturebased system, J. Dairy Sci. 86 (2003) 2658 2666.

[100] Ruegg P.L., Milton R.L., Body condition scores of Holstein cows on Prince Edward Island, Canada: relationships with yield, reproductive performance, and disease, $\mathrm{J}$. Dairy Sci. 78 (1995) 552-564.

[101] Sakata T., Tamata H., Rumen epithelium cell proliferation accelerated by rapid increase in interruminal butyrate, J. Dairy Sci. 61 (1978) 1109-1113.

[102] Saunders H.G., The variations in milk yields caused by season of the year, service, age and dry period, and their elimination. Part IV . dry period, and standardisation of yields, J. Agr. Sci. 18 (1928) 209-251.

[103] Sehested J., Andersen J.B., Aaes O., Kristensen N.B., Diernæs L., Møller P.D., Skadhauge E., Feed-induced changes in the transport of butyrate, sodium and chloride ions across the isolated bovine rumen epithelium, Acta Agr. Scand. A-An. 50 (2000) 47-55.

[104] Sejrsen K., Relationship between nutrition, puberty and mammary development, Proc. Nutr. Soc. 53 (1994) 103-111.

[105] Smith L., Waldron M.R., Overton T.R., Drackley J.K., Socha M.T., Metabolism of dairy cows as affected by prepartum dietary carbohydrate source and supplementation with chromium throughout the periparturient period, J. Dairy Sci. 86 (Suppl. 1) (2003) 106.

[106] Sørensen J.T., Enevoldsen C., Effect of dry period length on milk production in subsequent lactation, J. Dairy Sci. 74 (1991) 1277 1283.

[107] Strudsholm F., Foldager J., Gildbjerg L.B., Mave-tarmkanalens udvikling samt foderoptagelse og mælkeproduktion i første laktation hos kvier opdrættet på store og små mængder halm, Beretning fra Statens Husdyrbrugsforsøg No. 589, 1985, 69 p.

[108] Swanson E.W., Comparing continuous milking with sixty day dry periods in successive lactations, J. Dairy Sci. 48 (1965) 12051209.

[109] Tesfa A.T., Tuori M., Syrjälä-Qvist L., Pösö R., Saloniemi H., Heikonen K., Kivilahti K., Saukko T., Lindberg L.-A., The influence of dry period feeding on liver fat and postpartum performance of dairy cows, Anim. Feed Sci. Technol. 76 (1999) 275-295.

[110] Thilsing-Hansen T., Jørgensen R.J., Prevention of parturient paresis and subclinical hypocalcemia in dairy cows by zeolite A administration in the dry period, J. Dairy Sci. 84 (2001) 691-693.

[111] Thilsing-Hansen T., Jørgensen R.J., Østergaard S., Milk fever control principles: a review, Acta Vet. Scand. 43 (2002) 1-19.

[112] Treacher R.J., Reid I.M., Roberts C.J., Effect of body condition at calving on the health and performance of dairy cows, Anim. Prod. 43 (1986) 1-6.

[113] Van Saun R.J., Dry cow nutrition, the key to improving fresh cow performance, in: Sniffen C.J., Herdt T.H. (Eds.), Dairy Nutrition Management, Vet. Clin. N. Am. Food A 7 (1991) 599-620.

[114] Van Saun R.J., Idleman S.C., Sniffen C.J., Effect of undegradable protein amount fed prepartum on postpartum production in first lactation Holstein cows, J. Dairy Sci. 76 (1993) 236-244

[115] Vandehaar M.J., Yousif G., Sharma B.K., Herdt T.H., Emery R.S., Allen M.S., Liesman J.S., Effect of energy and protein density of prepartum diets on fat and protein metabolism of dairy cattle in the periparturient period, J. Dairy Sci. 82 (1999) 1282-1295.

[116] Vernon R.G., Pond C.M., Adaptations of maternal adipose tissue to lactation, J. Mammary Gland Biol. 2 (1997) 231-241.

[117] Wiggers K.D., Nelson D.K., Jacobson N.L., Prevention of periparturient paresis by a lowcalcium diet prepartum: a field study, J. Dairy Sci. 58 (1975) 430-431.

[118] Wilson G.F., Mackenzie D.D.S., Brookes I.M., Importance of body tissues as sources of nutrients for milk synthesis in the cows, using ${ }^{13} \mathrm{C}$ as a marker, Brit. J. Nutr. 60 (1988) 605-617.

[119] Wu Z., Fisher R.J., Polan C.E., Schwab C.G., Lactational performance of cows fed low or high ruminally undegradable protein prepartum and supplemental methionine and lysine postpartum, J. Dairy Sci. 80 (1997) 722-729. 